\title{
Pertumbuhan Karang Lunak Sarcophyton sp. yang Dibudidayakan di Teluk Awur, Jepara
}

\author{
Diah Permata Wijayanti*, Ayu Charismawaty, Elis Indrayanti, Agus Trianto \\ Departemen Ilmu Kelautan, Fakultas Perikanan dan Ilmu Kelautan, Universitas Dipenogoro \\ Jl. Prof. Soedarto SH, Kampus Tembalang, Semarang 50275 \\ Email: diah_permata@mail.com
}

\begin{abstract}
Abstrak
Upaya budidaya karang lunak di Indonesia masih kurang berkembang, terutama karang lunak yang bernilai jual tinggi. Sarcophyton adalah salah satu karang lunak yang sering dimanfaatkan sebagai pengisi akuarium. Namun seringkali produk yang dipasarkan berasal dari alam. Penemuan berbagai manfaat Sarcophyton sebagai kandidat bahan obat, turut menurunkan keberadaan keberadaan Sarcophyton di alam. Penelitian ini bertujuan untuk mengetahui pertumbuhan dan kelangsungan hidup fragmen karang lunak Sarcophyton sp. di perairan Teluk Awur, Jepara. Eksperimen dilakukan dengan menggunakan rancangan acak lengkap. Penelitian menggunakan fragmen dengan luas awal $\approx 10-12 \mathrm{~cm}^{2}$ dan $>12-15 \mathrm{~cm}^{2}$. Hasil penelitian menunjukkan tingkat kelangsungan hidup karang lunak Sarcophyton sp. berkisar antara 63,64$77,78 \%$. Pertumbuhan tertinggi ditemukan pada fragmen dengan luas awal $\approx 10-12 \mathrm{~cm}^{2}$ yakni sebesar $74,68 \pm 19,84 \mathrm{~cm}^{2}$ dengan laju pertumbuhan total $0.47 \mathrm{~cm}^{2} /$ hari. Pertumbuhan terendah terlihat pada fragmen dengan luas awal $>12-15 \mathrm{~cm}^{2}$ yakni sebesar $60,41 \pm 22,96 \mathrm{~cm}^{2}$ dengan laju pertumbuhan total $0.38 \mathrm{~cm}^{2} / \mathrm{hari}$. Ukuran luas awal fragmen $\approx 10-12 \mathrm{~cm}^{2}$ memiliki pertumbuhan yang lebih besar dibandingkan dengan fragmen karang lunak dengan ukuran luas awal $>12-15 \mathrm{~cm}^{2}$.
\end{abstract}

Kata Kunci: Pertumbuhan, Tingkat Kelangsungan Hidup, Karang Lunak, Sarcophyton sp.

\begin{abstract}
Efforts to soft coral cultivation in Indonesia are still underdeveloped, especially soft corals with high selling value. Sarcophyton is one of the soft coral that is often used as an aquarium ornament. But often the marketed products come from nature. The discovery of various benefits of Sarcophyton as a candidate ingredient of drugs, helped reduce the existence of Sarcophyton in nature.This study aims to determine the growth and survival of soft coral fragments Sarcophyton sp. in the waters of Awur Bay, Jepara. The experiment was performed using a complete randomized design. The study used fragments with an initial area $\approx 10-12 \mathrm{~cm}^{2}$ and $>12-15 \mathrm{~cm}^{2}$. The results showed the soft coral survival rate of Sarcophyton sp. ranged from 63.64 to $77.78 \%$. The highest growth was found in fragments with an initial area of $\approx 10-12 \mathrm{~cm}^{2}$ i.e of $74.68 \pm 19.84 \mathrm{~cm}^{2}$ with a total growth rate of $0.47 \mathrm{~cm}^{2} /$ day. The lowest growth was seen in fragments with an initial area of $>12-15 \mathrm{~cm}^{2}$, which was $60.41 \pm 22.96 \mathrm{~cm} 2$ with a total growth rate of $0.38 \mathrm{~cm}^{2} /$ day. The size of the initial fragment $\approx 10-12 \mathrm{~cm}^{2}$ has a larger growth compared to soft coral fragments with an initial baseline size $>12-15 \mathrm{~cm}^{2}$.
\end{abstract}

Keywords: Growth, Survival Rate, Soft Coral, Sarcophyton sp.

\section{PENDAHULUAN}

Fauna invertebrata laut, termasuk karang lunak telah lama dimanfaatkan sebagai sumber berbagai bahan obat alam yang bernilai farmaseutika dan kosmetika (Blunt et al., 2012; 2013), selain diperdagangkan sebagai hiasan akuarium (Barton et al., 2015). Permintaan yang tinggi menyebabkan karang lunak di banyak kawasan terumbu dunia dipanen dalam jumlah besar (Barton et al., 2015). Rusaknya habitat, yang disertai pengambilan yang berlebihan untuk keperluan hiasan akuarium maupun keperluan lain menyebabkan jumlah populasi karang lunak menurun dengan cepat. Lebih dari 1500 spesies biota dan tumbuhan perairan diperjual-belikan di seluruh dunia, $80 \%$ diantaranya sesungguhnya dapat dibudidayakan (Winfree, 1989). Sebanyak 1,5 juta karang diperdagangkan sejak 2007 dan sebagian besar berasal dari Indonesia (Bruckner dan Borneman, 2010). Salah satu spesies karang lunak yang dikhawatirkan mengalami penurunan jumlah adalah Sarcophyton sp.

\footnotetext{
*Corresponding author http://ejournal.undip.ac.id/index.php/buloma

buloma.undip@gmail.com

Diterima/Received : 31-01-2017

Disetujui/Accepted : 15-03-2017
} 
Temraz et al. (2006) menyatakan, selain pengambilan yang berlebihan untuk tujuan dijadikan hiasan pada akuarium air laut, saat ini Sarcophyton sp. banyak diambil untuk ekstraksi senyawa bioaktif. Sarcophyton glaucum yang tersebar luas di Indo-Pasifik diketahui memiliki kandungan senyawa bahan aktif yang beragam (Sella dan Banayahu, 2010). Sabdono dan Radjasa (2006) menunjukkan hasil isolasi enam bakteri yang berasosiasi dengan Sarcophyton sp. memiliki kemampuan menghalangi pertumbuhan sedikitnya satu dari tujuh isolat pembentuk bio-filum. $S$. crassocaule diketahui memiliki potensi sitotoksik terhadap sel kanker kandung kemih (Su et al., 2011). Sarcophyton juga dinyatakan mengandung diterpenoid laut yang dapat dimanfaatkan sebagai agen anti-inflamasi (Gonzalez et al., 2015). Aktivitas anti-bakterial juga ditemukan pada $S$. trocheliophorum (Gomaa et al., 2015).

Meningkatnya permintaan akan karang ornamental tidak dibarengi dengan peningkatan penyediaan stock di alam. Kondisi ini kemudian melahirkan beragam teknik untuk membudidayakan species tersebut (Ellis dan Sharon, 1999; Ellis dan Ellis, 2002). Saat ini karang dibudidayakan dengan 3 tujuan utama yaitu sebagai sediaan bioprospeksi yang berpotensi sebagai bahan obat (Blunt et al., 2012, 2013; Leal et al., 2013; Rocha et al., 2011), untuk biota pengisi akuarium (Olivotto et al., 2011; Rhyne et al., 2012) dan untuk keperluan restorasi terumbu (Rinkevich, 2005; Shafir et al., 2006). Propagasi karang berdasar kemampuan bereproduksi secara aseksual, menjadi metode yang umum digunakan untuk memproduksi banyak anakan guna keperluan budidaya (Soong dan Chen, 2003; Olivotto et al., 2011; Rhyne et al., 2012; Yunus et al, 2013; Wijayanti et al., 2015).

Sarcophyton sendiri telah dicoba untuk dibudidayakan sebagai sediaan bahan obat maupun sebagai hiasan akuarium (Sella dan Benayahu, 2010; Leal et al., 2013; Costa et al., 2016). Sella dan Benayahu (2010) melakukan budidaya dengan teknik pemotongan koloni dan dilakukan pada sistem tertutup. Sarcophyton juga dicoba dibudidayakan menggunakan cahaya dengan intensitas rendah (Rocha et al., 2013). Costa et al. (2016) melakukan budidaya ex-situ system re-sirkulasi air dengan pemberian pakan rotifer.

Upaya penelitian karang lunak di Perairan Indonesia masih sangat sedikit dan kurang berkembang (Manuputty, 2010). Saat ini penelitian yang melibatkan karang lunak sebagai objek, umumnya ditujukan untuk mencari potensi senyawa aktif yang terkandung di dalamnya (Anta et al., 2002; Kapojos et al., 2008; Januar et al., 2010; Soedharma et al., 2005). Penelitian yang bertujuan untuk mengetahui pertumbuhan dan kelangsungan hidup transplan karang lunak Sarcophyton sp. masih jarang dilakukan (Rocha et al., 2013). Penelitian ini diharapkan dapat memberi informasi tentang pertumbuhan dan tingkat kelangsungan hidup karang lunak Sarcophyton sp. sekaligus memberi informasi tentang potensi pemanfaatan perairan Teluk Awur dalam upaya budidaya karang lunak.

\section{MATERI DAN METODE Pengambilan dan Persiapan Sampel}

Sampel berupa koloni sehat dari Sarcophyton sp. Koloni induk diambil dari Perairan Bandengan, Kabupaten Jepara (S 063'057” E 110³9'257'). Perairan Bandengan dipilih karena kondisi koloni Sarcophyton sp. yang ditemukan di perairan Bandengan sangat baik. Selain jumlah koloni yang banyak, ukuran koloni yang hidup di Perairan Bandengan rata-rata berdiameter lebih dari $1 \mathrm{~m}$. Sampel diperoleh dari 5 koloni induk yang berdiameter $\pm 20-50 \mathrm{~cm}$. Setiap koloni induk hanya diambil $25 \%$ dari seluruh luas permukaan koloni untuk menghindari kematian induk donor. Fragmen dipotong menggunakan cutter di bagian mahkota koloni (Ellis dan Ellis, 2002; Rocha et al., 2013). Selanjutnya fragmen yang diperoleh dimasukkan kotak pengangkut yang telah diberi air laut sebagai media dan dibawa ke Laboratorium Basah Marine Station Teluk Awur Jepara untuk dilakukan proses aklimatisasi selama 7 hari.

Fragmen yang telah diaklimatisasi selanjutnya dipotong menggunakan cutter dengan ukuran diameter $\approx 10-12 \mathrm{~cm}^{2}$ sebanyak 11 fragmen dan 12-15 $\mathrm{cm}^{2}$ sebanyak 9 fragmen. Jumlah fragmen menyesuaikan sediaan fragmen yang telah diaklimatisasi. Selanjutnya sampel ditanam di media substrat semen berdiameter $\pm 10 \mathrm{~cm}$ dan ketebalan $\pm 2,5 \mathrm{~cm}$ sebelum dipindahkan ke media budidaya berupa rak budidaya. Fragmen direkatkan menggunakan cable ties kecil. Fragmen disusun secara acak di dalam rak budidaya untuk mengurangi perbedaan kondisi penanaman sebesar mungkin. Jarak tanam setiap fragmen $10 \mathrm{~cm}$, agar saat fragmen tumbuh tidak saling bersentuhan.

\section{Penanaman Sampel di Rak Budidaya}

Fragmen karang lunak ditanam di rak budidaya yang terbuat dari besi $\mathrm{L}$ dengan ukuran 
1x1 m dan tinggi dari dasar laut sekitar $75 \mathrm{~cm}$. Kerangka rak besi kemudian dilapisi dengan jaring-jaring yang berfungsi untuk meletakkan fragmen dan sebagai pelindung dari gangguan arus maupun penumpukan sedimen. Setiap kakikaki rak budidaya dilengkapi dengan pot yang berisi semen untuk menguatkan struktur rak budidaya saat ditanam di lokasi budidaya.

Selanjutnya rak budidaya diletakkan di Perairan Teluk Awur, Jepara (S 06 ${ }^{\circ} 36^{\prime}$ 58,7' dan E $\left.110^{\circ} 38^{\prime} 18,8^{\prime \prime}\right)$. Lokasi budidaya dipilih berdasar pertimbangan bahwa di wilayah tersebut terdapat banyak koloni karang hidup, sehingga dianggap memiliki kesesuaian dengan habitat alami karang lunak. Selain itu lokasi juga jauh dari gangguan aktivitas manusia dan memiliki kedalaman yang cukup untuk kehidupan dan pertumbuhan karang lunak. Rak budidaya ditanam pada kedalaman $3 \mathrm{~m}$.

\section{Pengambilan Data}

Penelitian dilakukan dengan menggunakan Rancangan Acak Lengkap. Pengamatan dilakukan selama 160 hari (14 Juni 2012 hingga Desember 2012). Fragmen diamati setiap 2 minggu sekali dengan mencatat pertumbuhan fragmen menggunakan jangka sorong. Pada saat pengukuran juga dilakukan pengmabilan foto fragmen menggunakan kamera bawah air. Hasil foto kemudian diolah menggunakan software CPCe (Coral Point Count with Excel extension) untuk mengetahui pertambahan jumlah luasan karang lunak. Software CPCe dikembangkan oleh National Coral Reef Institute dan Oceanographic Center, Nova Southeastern University (Kusumo, 2012). CPCe dirancang untuk menghitung secara cepat tutupan karang, panjang serta luas koloni karang melalui gambar (Kohler dan Gill, 2006).

\section{Analisis Data}

Analisis yang digunakan untuk mengolah data menggunakan analisis deskriptif. Data dianalisis dengan perhitungan sebagai berikut :

1. Tingkat Kelangsungan Hidup (Survival Rate) Perhitungan dilakukan dengan menggunakan persamaan (Ricker, 1975 dalam Pratama 2005): $\mathrm{SR}=(\mathrm{Nt} / \mathrm{N} 0) \times 100 \%$

$\mathrm{SR}=$ Kelulushidupan

$\mathrm{Nt}=$ Jumlah transplan yang hidup

N0 = Jumlah awal yang ditransplan

2. Pertumbuhan (Growth)

Menurut Supriyanto (2000) dalam Kaleka (2004) pertumbuhan fragmen karang lunak dapat diketahui dengan menggunakan rumus:
Pertambahan Panjang = panjang akhir panjang awal

3. Laju pertumbuhan karang lunak

Menggunakan persamaan yang terdapat pada Sadarun (1999), yaitu :

$$
\beta=\frac{L t+1-l 1}{t i+1-t 1}
$$

Keterangan :

$\beta$ : Laju pertumbuhan panjang/lebar karang lunak $(\mathrm{cm})$

Lt+1 : Rata-rata panjang/lebar karang lunak pada waktu ke-t+1 $(\mathrm{cm})$

Lt : Rata-rata panjang/lebar karang lunak ada saat waktu ke-1 (cm)

Ti+1 : Waktu pengamatan ke-i+1

Ti : Waktu pengamatan ke-t

\section{HASIL DAN PEMBAHASAN}

Fragmen karang lunak menunjukkan respon stres saat dilakukan pemotongan. Fragmen Sarcophyton sp. nampak mengkerut dan menjadi keras. Sebagai respon terhadap perubahan kondisi lingkungan, karang lunak mengalami penyusutan jaringan. Saat fragmen dipindahkan ke bak aklimatisasi selain mengalami penyusutan tubuh, fragmen karang lunak juga mengeluarkan lendir.

\section{Tingkat Kelangsungan Hidup Fragmen Sarcophyton sp.}

Berdasarkan penelitian selama 160 hari diperoleh tingkat kelangsungan hidup Sarcophyton sp. dengan luas awal fragmen $\approx 10-12$ $\mathrm{cm} 2$ sebesar $63.64 \%$, sedangkan fragmen dengan ukuran awal $>12-15 \mathrm{~cm} 2$ tingkat kelangsungan hidupnya sebesar $77.78 \%$ (Tabel 1).

Dari jumlah total 11 fragmen ukuran awal $\approx 10-12 \mathrm{~cm}^{2}, 3$ fragmen mengalami penurunan luas mahkota pada hari ke-9 (Gambar 1). Hari ke-9, 2 fragmen dengan luas awal > 12-15 $\mathrm{cm}^{2}$ mengalami kematian. Selanjutnya fragmen yang tersisa mampu bertahan sampai hari pengukuran terakhir, sehingga jumlah fragmen yang mampu bertahan hingga akhir sebanyak 7 fragmen. Hari ke-90, 4 buah fragmen dengan luas awal $\approx 10-12$ $\mathrm{cm}^{2}$ mengalami kematian. Dengan demikian total 7 fragmen $\approx 10-12 \mathrm{~cm}^{2}$ yang mampu bertahan hingga hari pengamatan terakhir (Tabel 1).

Hasil penelitian menunjukkan tingkat kelangsungan hidup Sarcophyton sp. adalah $63,64 \%$ (fragmen $\approx 10-12 \mathrm{~cm}^{2}$ ) dan $77,78 \%$ (fragmen > 12-15 $\mathrm{cm}^{2}$ ). Mahardini (2011) pada penelitiannya menyampaikan tingkat kelangsungan hidup Sarcophyton sp. Sebesar $100 \%$. Perbedaan ini terjadi karena adanya 

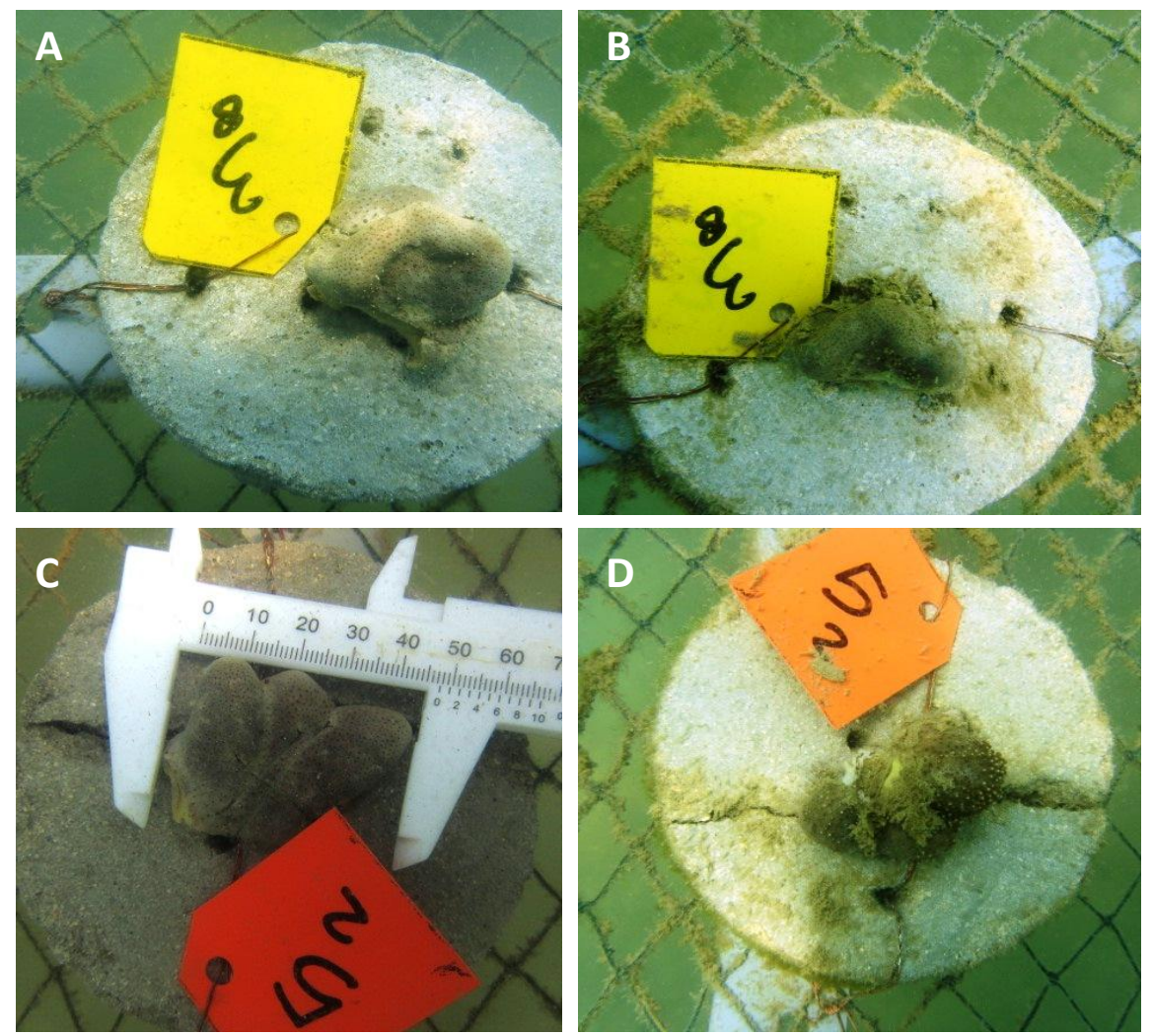

Gambar 1. Fragmen Sarcophyton sp. (A) fragmen $\approx 10-12 \mathrm{~cm}^{2}$ saat awal penanaman, (B) Fragmen $\approx 10-12$ $\mathrm{cm}^{2}$ pada hari ke-9, (C) Fragmen $>12-15 \mathrm{~cm}^{2}$ saat awal penanaman, (D) Fragmen $>12-15 \mathrm{~cm}^{2}$ saat pengukuran pada hari ke-9.

Tabel 1. Data Kelangsungan Hidup Fragmen Sarcophyton sp.

\begin{tabular}{|c|c|c|c|c|}
\hline \multirow{2}{*}{$\begin{array}{l}\text { Ukuran Awal } \\
\text { Fragmen }\end{array}$} & \multicolumn{3}{|c|}{ Jumlah Fragmen } & \multirow{2}{*}{$\begin{array}{c}\text { Tingkat Kelangsungan } \\
\text { Hidup }\end{array}$} \\
\hline & Awal & Mati & Sisa & \\
\hline$\approx 10-12 \mathrm{~cm}^{2}$ & 11 & 4 & 7 & $63,64 \%$ \\
\hline$>12-15 \mathrm{~cm}^{2}$ & 9 & 2 & 7 & $77,78 \%$ \\
\hline
\end{tabular}

perbedaan lingkungan penelitian. Penelitian oleh Mahardini (2011) dilaksanakan di laboratorium dengan parameter lingkungan terkontrol, sehingga sesuai dengan kondisi optimal yang dibutuhkan oleh karang lunak untuk hidup. Selain itu sedimentasi dianggap tidak berpengaruh terhadap pertumbuhan karang lunak yang dilakukan pada bak penanaman. Sedangkan pada penelitian yang dilaksanakan di perairan dengan kondisi perairan yang fluktuatif, menyebabkan fragmen mengalami tekanan dari lingkungan yang lebih beragam. Sehingga menyebabkan sejumlah fragmen tidak mampu bertahan dan mati.

Budidaya sistem tertutup memberikan keuntungan dalam budidaya Sarcophyton secara masal karena lebih terkontrol. Namun faktor lingkungan laut ternyata berpengaruh besar pada hasil pertumbuhan fragmen (Sella dan Benayahu, 2010). Budidaya sistem tertutup juga diterapkan pada budidaya Sarcophyton yang diikuti dengan pemberian cahaya degan intensitas rendah.Tujuannya untuk mengurangi biaya selama pemeliharaan. Hasil penelitian menunjukkan bahwa cahaya intensitas rendah tidak berpengaruh secara signifikan terhadap sintasan dan pertumbuhan fragmen. Intensitas cahaya yang rendah terbukti mengurangi biaya pemeliharaan tanpa mengurangi kemampuan fragmen berfotosintesa dan menghasilkan senyawa bioaktif melalui zooxanthella (Rocha et al., 2013). Namun teknik ini membutuhkan instalasi yang memadai agar potensi Sarcophyton sebagai penghasil senyawa bioaktif tidak mengalami 
penurunan (Rocha et al., 2013). Namun saat budidaya dilakukan di laut, potensi karang lunak untuk menghasilkan senyawa aktif menurun (Yulianti, 2009). Fragmen Sinularia dan Lobophytum memiliki aktivitas hambat yang menurun setelah ditanam di lokasi budidaya, yaitu di Pulau Seribu. Diduga kondisi lingkungan laut mempengaruhi senyawa aktif yang dihasilkan masing-masing species karang lunak (Yulianti, 2009).

Budidaya di laut memberikan keuntungan tidak diperlukannya pemberian pakan secara rutin untuk mendukung pertumbuhan fragmen. Percobaan pemberian pakan rotifer pada fragmen Sarcophyton yang dilakukan Costa et al. (2016) menunjukkan bahwa pemberian pakan rotifer tidak memberi pengaruh nyata pada pertumbuhan Sarcophyton cf. glaucum.

\section{Pertumbuhan Fragmen Sarcophyton sp.}

Hasil penelitian menunjukkan bahwa fragmen Sarcophyton sp. ukuran $\approx 10-12 \mathrm{~cm}^{2}$ memiliki nilai rata-rata pertumbuhan $74,68 \pm 19,85$ $\mathrm{cm}^{2}$ dengan laju pertumbuhan $0,47 \mathrm{~cm}^{2} /$ hari. Sedangkan untuk fragmen Sarcophyton sp. dengan ukuran awal $>12-15 \mathrm{~cm}^{2}$ diketahui memiliki rata-rata pertumbuhan $60,41 \pm 22,96 \mathrm{~cm}^{2}$, laju pertumbuhan $0,38 \mathrm{~cm}^{2} /$ hari (Tabel 2).

Masa kritis pertumbuhan terjadi ketika waktu awal pertambahan luas pertama hingga hari ke-9. Pada penelitian ini seluruh fragmen mengalami fase penyesuaian lingkungan. Kedua ukuran awal fragmen mengalami pertumbuhan yang meningkat sejak hari ke-25 hingga hari ke42 (Gambar 2).

Fragmen karang lunak melekat pada substrat dengan cara meregenerasi dan memperluas jaringan dengan membentuk jaringan yang lunak dan jaringan kerangka (Soong dan Chen, 2003). Hari ke-42 fragmen mampu menempel dengan sempurna secara keseluruhan. Fragmen karang lunak dinyatakan berada pada kondisi yang baik. Tubuh karang lunak Sarcophyton sp. terlihat mengembang sempurna serta tentakel-tentakel menjulur keluar. Hari ke-55 suhu perairan tercatat $29^{\circ} \mathrm{C}$, salinitas $34 \%$ dan $\mathrm{pH}$ 7. Tingkat keasaman $(\mathrm{pH})$ berada di bawah batas optimal untuk pertumbuhan karang lunak. Hari ke-55 Sarcophyton sp. dengan luas awal >12-15 $\mathrm{cm}^{2}$ mengalami penurunan luas sebesar $1,31 \mathrm{~cm}^{2}$.

Berbagai penelitian menunjukkan bahwa, ukuran awal fragmen berpengaruh besar dalam kelulushidupan dan laju pertumbuhan fragmen, baik karang keras (Bowden-Kerby, 2001; Soong and Chen, 2003; Okubo et al., 2005; Forsman et al., 2006, Habibi et al., 2013, Shafir dan Rickevich, 2013; Diah Permata et al., 2015) maupun karang lunak (Rocha et al., 2003). Namun pada penelitian ini, fragmen dengan ukuran awal lebih besar justru memiliki pertumbuhan yang lebih lambat. Hal ini diduga bahwa kondisi fragmen yang luas cenderung mengakumulasi sedimen lebih banyak dibandingkan fragmen dengan luasan yang lebih kecil. Kondisi lingkungan seperti sedimentasi, predasi, dan kompetisi turut mempengaruhi pertumbuhan fragmen yang dibudidayakan di laut (Vijayavel dan Richmond, 2012; Shafir dan Rinkevich, 2013. Diketahui kondisi Teluk Awur saat budidaya dilakukan mengalami sedimentasi yang tinggi, sehingga memberi pengaruh terhadap pertumbuhan fragmen (Tabel 3).

Perairan mengalami surut yang sangat rendah pada hari ke-90 hingga ke-112. Surut drastis mengakibatkan kedalaman perairan menyusut hingga mencapai $120 \mathrm{~cm}$. Data luasan fragmen Sarcophyton sp. terus mengalami penurunan sejak hari ke-90. Hari ke-112 pertumbuhan fragmen karang lunak mengalami penurunan sebesar $0,65 \mathrm{~cm}^{2}$ untuk fragmen berukuran awal $\approx 10-12 \mathrm{~cm}^{2}$ dan fragmen dengan ukuran awal $>12-15 \mathrm{~cm}^{2}$ mengalami penurunan sebesar $7,31 \mathrm{~cm}^{2}$. Pada pengambilan data hari ke112 kondisi karang lunak diperparah dengan sedimentasi yang tinggi hingga menutupi hampir seluruh bagian tubuh karang lunak. Fabricius dan Alderslade (2001) menjelaskan bahwa adukan sedimen yang tinggi dapat menyerap asupan cahaya sehingga menghambat proses fotosintesis. Sedimentasi yang tebal juga mampu menekan karang lunak dengan menutupi sebagian atau seluruh tubuh karang lunak.

Laju sedimentasi terendah perairan Teluk Awur tercatat sebesar $10,2 \mathrm{~g} / \mathrm{cm}^{2} /$ hari. Laju

Tabel 2. Data Pertumbuhan dan Laju Pertumbuhan Total Sarcophyton sp.

\begin{tabular}{ccc}
\hline Luas awal fragmen & Rata-rata pertumbuhan $\left(\mathrm{cm}^{2} \pm \mathrm{SD}\right)$ & $\begin{array}{c}\text { Pertumbuhan per } \\
\text { hari }\left(\mathrm{cm}^{2} / \text { hari }\right)\end{array}$ \\
\hline$\approx 10-12 \mathrm{~cm}^{2}$ & $74,68 \pm 19,85$ & 0.47 \\
$>12-15 \mathrm{~cm}^{2}$ & $60,41 \pm 22,96$ & 0.38 \\
\hline
\end{tabular}




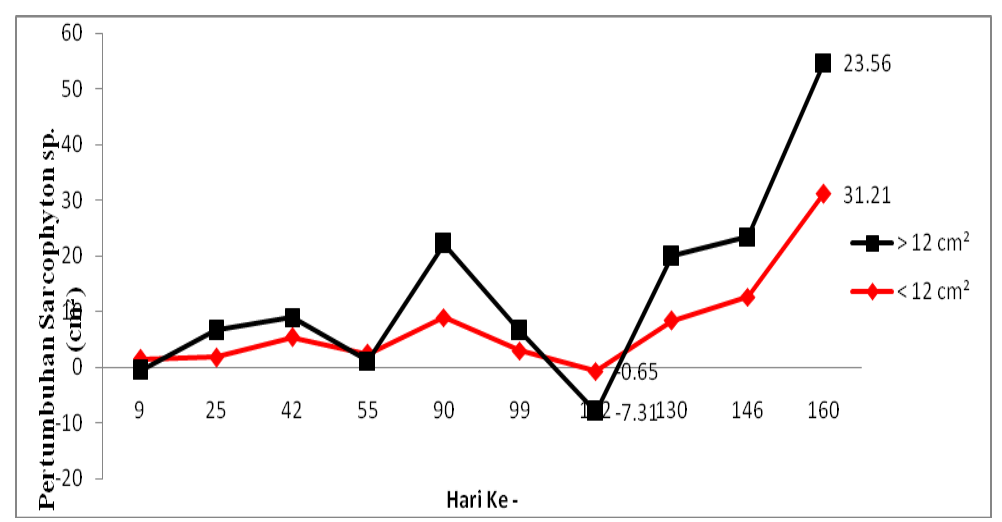

Gambar 2. Grafik Pertumbuhan Sarcophyton sp.

Tabel 3. Data Laju Sedimentasi

\begin{tabular}{crrrrrr}
\hline Sedimen & \multicolumn{6}{c}{ Laju Sedimentasi Pengamatan ke $-\left(\mathrm{g} / \mathrm{cm}^{2} / \mathrm{hari}\right)$} \\
\cline { 2 - 7 } Trap & I & II & III & IV & V \\
\hline A & 9.1 & 7.6 & 7.7 & 27.7 & 53.2 \\
B & 16.1 & 7.6 & 14.7 & 18.7 & 55.1 \\
C & 10.8 & 15.4 & 8.4 & 18.0 & 46.7 \\
\hline Rata-rata $\left(\mathrm{g} / \mathrm{cm}^{2} /\right.$ hari & 12.0 & 10.2 & 10.3 & 21.5 & 51.7 \\
\hline St. Deviasi & 3.65 & 4.5 & 3.8 & 5.4 & 4.4 \\
\hline
\end{tabular}

sedimentasi ini masuk kategori sedang-bahaya (Tabel 3). Laju sedimentasi tertinggi perairan Teluk Awur tercatat $51,7 \mathrm{~g} / \mathrm{cm}^{2} /$ hari yang tergolong kategori bahaya-katastropik, hal ini dapat berdampak pada menurutnya kelimpahan karang secara drastis, kerusakan parah pada komunitas, kematian koloni karang, hampir tidak terjadi peremajaan di ekosistem tersebut, serta munculnya spesies baru yang menginvasi (Supriharyono, 2007).

Kondisi perairan yang mengalami surut selama beberapa waktu pengamatan diperkirakan mempengaruhi pertumbuhan fragmen Sarcophyton sp. Alga dan lumut nampak menutupi substrat buatan, bahkan hingga permukaan fragmen Sarcophyton sp. Luas fragmen karang lunak menurun pada hari ke-99 dan 112. Penurunan luas terbesar terjadi pada fragmen dengan luas awal $>12-15 \mathrm{~cm}^{2}$ yakni sebesar 7,31 cm2. Luas fragmen karang lunak meningkat pada hari ke-130 hingga hari ke-160.

Fragmen dengan ukuran awal $<\approx 10-12$ $\mathrm{cm} 2$ tercatat mengalami pertambahan luas hingga $74,7 \mathrm{~cm} 2$. Fragmen berukuran $>>12-15 \mathrm{~cm}^{2}$ mengalami pertumbuhan sebesar $60,4 \mathrm{~cm}^{2}$. Kondisi ini berbeda dengan yang terjadi pada penelitian laboratorium. Pertumbuhan Sarcophyton sp. tercatat mengalami penyusutan sebesar luas $3,8 \mathrm{~cm} 2$ (laju pertumbuhannya mengalami penurunan 0,54 cm2/minggu) (Mahardini, 2011). Penyusutan dialami pula pada penelitian yang dilakukan di lapangan, namun hal ini hanya menjadi respon awal ketika fragmen sedang menyesuaikan diri pada lingkungannya sebelum mampu tumbuh, serta ketika terjadi penurunan permukaan air laut (surut) yang drastis.

\section{KESIMPULAN}

Berdasarkan hasil penelitian yang telah dilakukan, dapat disimpulkan bahwa transplan karang lunak Sarcophyton sp. mampu hidup di perairan Teluk Awur, Jepara dengan rerata tingkat kelangsungan hidup Sarcophyton sp. berkisar antara 63,6-77,8 \%. Pertumbuhan transplan karang lunak Sarcophyton sp. tertinggi terlihat pada fragmen karang dengan ukuran $\approx 10-12 \mathrm{~cm}^{2}$ yakni sebesar $74,7 \pm 19,8 \mathrm{~cm}^{2}$. Untuk fragmen dengan luas awal $>12-15 \mathrm{~cm}^{2}$ memiliki pertumbuhan sebesar $60.4 \pm 23 \mathrm{~cm}^{2}$. Ukuran luas awal fragmen $\approx 10-12 \mathrm{~cm}^{2}$ memiliki pertumbuhan yang lebih tinggi dibandingkan dengan fragmen karang lunak dengan ukuran luas awal >12-15 $\mathrm{cm}^{2}$, meskipun tidak signifikan.

\section{UCAPAN TERIMAKASIH}

Penulis mengucapkan terima kasih kepada DP2M Direktorat Jenderal Pendidikan Tinggi, Kementerian Pendidikan Nasional yang telah 
memberi bantuan pendanaan melalui Hibah Kompetensi 2011 dengan Surat Perjanjian Pelaksanaan Penugasan Penelitian Hibah Kompetensi Nomor: 353/SP2H/PL/Dit.Litabmas/ IV/2011, tanggal 14 April 2011.

\section{DAFTAR PUSTAKA}

Anta C, N Gonzalez, G Santafe, J Rodriguez, C Jimenez. 2002. New Xenia Diterpenoids from the Indonesian Soft Coral Xenia sp. J. Nat. Prod., 2002, 65 (5), pp 766-768 doi: 10.1021/np010488x

Barton JA, Willis BL, KS Hutson. 2015. Coral propagation: a review of techniques for ornamental trade and reef restoration. Reviews in Aquaculture 10:1-19

Bowden-Kerby A. 2001. Low-tech coral reef restoration methods modeled after natural fragmentation processes. Bulletin of Marine Science. 69:915-931.

Blunt, J.W., B.R Copp, RA Keyzers, MHG Munro, MR Prinsep. 2012. Marine natural products. Nat. Prod. Rep. 29, 144-222.

Blunt, J.W., B.R Copp, RA Keyzers, MHG Munro, MR Prinsep. 2013. Marine natural products. Nat. Prod. Rep. 30, 237-323.

Bruckner, W. A. and H. E. Borneman. 2010. Implication of coral harvest and Transplantation on Reefs in Northwestern Dominica. NOAA Fisheries Office of Habitat Conservation. University of Houston. Houston TX USA. Rev. Biol. Trop. Int. J. Trop. Biol. 58(3):111-127.

Costa APL, R Calado, B Marques, AI Lillebø, J Serôdio, AMVM Soares, EA Serrão, RJM Rocha. 2016. The effect of mixotrophy in the ex situ culture of the soft coral Sarcophyton cf. glaucum. Aquaculture, 452:151-159

Ellis, S. and L. Sharron. 1999. The Culture of Soft Coral (Order: Alcyonacea) for The Marine Aquarium Trade. Center Tropical and Sub Tropical Aquaculture. 137.

Ellis S, E Ellis. 2002. Recent Advances in Lagoon-Based Farming Practices for Eight Species of Commercially Valuable Hard and Soft Corals: A Technical Report. Center for Tropical and Subtropical Aquaculture, Waimanalo, USA 59 pp.

Fabricius, K, P. Alderslade. 2001. Soft Coral and Sea Fans; A Comprehensive Guide to The Tropical Shallow Water Genera of The Central-west Pasific, The Indian Ocean and the Red Sea. Autralian Institute of Marine Science and The Museum and Art Gallery of The Northern Territory. Melbourne Australia.
Forsman ZH, B Rinkevich, CL Hunter. 2006. Investigating fragment size for culturing reefbuilding corals (Porites lobata and $P$. compressa) in ex situ nurseries. Aquaculture 261: 89-97.

Yunus BH, CH Adhi Suryo, DP Wijayanti. 2013. Transplantasi Karang Acropora aspera dengan Metode Tali di Perairan Teluk Awur, Jepara. Buletin Oseanografi Marina. 2:22-28

Gomaa MN, K Soliman, A Ayesh, AA El-Wahed, Z Hamza, HM. Mansour, SAM Khalifa, HBM Ali HR El-Seedi. 2015. Marine Diterpenoids as Potential Anti-Inflammatory Agents Antibacterial effect of the red sea soft coral Sarcophyton trocheliophorum. Natural Product Research. doi : 10.1080/14786419. 2015.1040991

González Y, DT Mendoza, GE Jones, PL Fernandez. 2015. Mediators of Inflammation. 263543-263551, doi : 10.1155 /2015/263543

Januar HI, E Chasanah, CA Motti, DM Tapiolas, CH Liptrot, AD Wright. 2010. Cytotoxic Cembranes from Indonesian Specimens of the Soft Coral Nephthea sp. Mar. Drugs, 8(7):2142-2152; doi:10.3390/md8072142

Kaleka, D. M. W. 2004. Transplantasi Karang Batu Marga Acropora pada Substrat Buatan di Perairan Tablolong Kabupaten Kupang. Makalah Perorangan Semester Ganjil 2004 Falsafah Sains (PPS702) Program S3. Institut Pertanian Bogor.

Kapojos MM, REP Mangindaan, T Nakazawa, T Oda, K, Ukai, M Namikoshi. 2008. Three New Nardosinane Type Sesquiterpenes from an Indonesian Soft Coral Nephthea sp. Chem. Pharm. Bull. 56(3):332-334

Khalesi, M. K. 2008. Ex Situ Cultivation of Soft Coral Sinularia flexibilis for Biotechnological Exploitation. Ph.D. Thesis, Wageningen University, the Netherlands.

Kohler, K.E. and S.M. Gill. 2006. Coral Point Count with Excel extensions (CPCe): A Visual Basic Program for The Determination of Coral and Substrate Coverage using Random Point Count Methodology. Computer and Geosci. 32(9):1259-1269.

Kusumo, S. 2012. Panduan Penggunaan CPCe 4.1 Untuk Pengamatan Pertumbuhan Karang (Uji Coba Transplantasi Karang Hias). Cibubur.

Leal MC, R Calado, C Sheridan, A Alimonti, R Osinga. 2013. Coral aquaculture to support drug discovery Trends in Biotechnology. doi : 10.1016/j.tibtech.2013.06.004 
Mahardini, A. 2011. Pertumbuhan Karang Lunak pada Kondisi Penangkaran untuk Menuju Upaya Budidaya. [Skripsi]. Fakultas Perikanan dan Ilmu Kelautan. Universitas Diponegoro, Semarang, $38 \mathrm{hlm}$.

Manuputty, A. E. W. 2010. Sebaran Karang Lunak, Marga Sinularia May, 1898 (Octocorallia, Alcyonacea) di Pulau - Pulau Derawan, Kalimantan Timur. Oseanologi dan Limnologi di Indonesia. 36(2):211 - 225.

Okubo N, H Taniguchi, T Motokawa. 2005. Successful methods for transplanting fragments of Acropora formosa and Acropora hyacinthus. Coral Reefs 24:333342.

Olivotto, I., Planas, M., Simões, N., Holt, G.J., Avella, M.A., Calado, R., 2011. Advances in

breeding and rearing marine ornamentals. $J$. World Aquac. Soc. 42:135-166

Pratama, J. 2005. Tingkat Kelangsungan Hidup dan Laju Pertumbuhan Karang Pocillopora, dan Heliopora dalam Transplantasi Karang di Pulau Pari, Kepulauan Seribu. Skripsi. Fakultas Perikanan dan Ilmu Kelautan. Institut Pertanian Bogor. Bogor.

Rinkevich B. 1995. Restoration strategies for coral reefs damaged by recreational activities: the use of sexual and asexual recruits. Restoration Ecology. 3:241-251.

Rhyne, A.L., Tlusty, M.F., Kaufman, L., 2012. Long-term trends of coral imports into the United States indicate future opportunities for ecosystem and societal benefits. Conserv. Lett. 5:478-485

Rocha RJM, R Calado, P Cartaxana, J Furtado, J Serôdio. 2013. Photobiology and growth of leather coral Sarcophyton cf. glaucum fragments stocked under low light in a recirculated system. Aquaculture 414(415): 235-242

Sabdono, A. and O, Karna Radjasa. 2006. Antifouling Activity of Bacteria Associated With Soft Coral Sarcophyton sp, Against Marine Biofilm-Forming Bacteria. Journal of Coastal Development. 10(1):55-62.

Sadarun. 1999. Tranplantasi Karang Batu di Kepulauan Seribu, Teluk Jakarta. Tesis. Fakultas Perikanan dan Ilmu Kelautan. Institut Pertanian Bogor. 67p.

Shafir S, B Rinkevich. 2013. Mariculture of coral colonies for the public aquarium sector. In: Leewis RJ, Janse M (eds) Advances in Coral Husbandry in Public Aquariums. Burgers' Zoo, Arnhem, Netherlands. 2:315-318.
Shafir S, J Rijn, B Rinkevich. 2006. Steps in the construction of underwater coral nursery, an essential component in reef restoration acts. Marine Biology. 149: 679-687.

Soedharma D, M Kawaroe, A Haris. 2005. Kajian potensi bioaktif karang lunak (Octocorallia:Alcyonacea) di Perairan Kepulauan Seribu, DKI Jakarta. Jurnal Ilmuilmu Perairan dan Perikanan Indonesia, Jilid 12, Nomor 2: 121-128

Soong, K. and T. Chen. 2003. Coral Transplantation: Regeneration and Growth of Acropora Fragments in a Nursery. Society for Ecological Restoration International. Institute of Marine Biology, National Sun Yat-sen University, Kaohsiung, 804. Taiwan.

Su CC, JH Su, JJ Lin, CC Chen, WI Hwang, HH Huang, YJ Wu. 2011. An Investigation into the Cytotoxic Effects of 13Acetoxysarcocrassolide from the Soft Coral Sarcophyton crassocaule on Bladder Cancer Cells Mar. Drugs , 9 (12): 2622-2642

Supriharyono. 2007. Pengelolaan Ekosistem Terumbu Karang. Penerbit Djambatan, Jakarta.

Temraz, T.A., Houssen, W.E., Jaspars, Marcel., Woolley, David R., Wease, Kerrie N., Davies, Steven., and Scott, Roderick H. 2006. A Pyridinium derivative from Red Sea Soft Corals Inhibited Voltage-activated Potassium Conductances and Increased Excitability of Rat Cultured Sensory Neurons. Research Article. BMC Pharmacology.

Vijayavel K, RH Richmond. 2012.The preparation of the rice coral Montipora capitata nubbins for application in coral-reef ecotoxicology. Ecotoxicology 21: 925-930.

Winfree, R.A. 1989. Tropical fish: their production and marketing in the U.S. World Aquaculture 20(3):24-30

Wijayanti, DP, E Indrayanti, Wandi FA, Ambariyanto. 2015. Pertumbuhan Karang Transplan Genus Favia dan Favites Berdasarkan Jumlah Polip. Indonesian 20(1):23-32.

Yulianti, I. 2009. Bioaktivitas ekstrak karang lunak Sinularia sp dan Lobophytum sp hasil fragmentasi pada kedalaman $3 \mathrm{~m}$ dan $10 \mathrm{~m}$ di Perairan Pulau Pramuka, Kepulauan Seribu, Jakarta. Tesis. Repository Institut Pertanian Bogor. 